\title{
Knowledge of farmers about animal management and prevalence of reproductive disorders in cows at Babugonj Upazila under Barisal district of Bangladesh
}

\author{
A. K. Paul, P. K. Mittra ${ }^{1}$, P. K. Sarkar ${ }^{2}$ and P. K. Howlader ${ }^{3}$
}

Department of Medicine, Surgery and Obstetrics, Faculty of Animal Science and Veterinary Medicine, Patuakhali Science and Technology University, Barisal Campus, Barisal-8210, Bangladesh.

${ }^{1}$ Department of Basic Science, ${ }^{2}$ Department of Poultry Science, Faculty of Animal Science and Veterinary Medicine, Patuakhali Science and Technology University, Barisal Campus, Barisal-8210, Bangladesh.

${ }^{3}$ Central Disease Investigation Laboratory, Department of Livestock Services, Dhaka.

\begin{tabular}{|c|c|}
\hline ARTICLE INFO & $\mathbf{A b}$ \\
\hline $\begin{array}{l}\text { Article history: } \\
\text { Received: } 22 \text { October } 2017 \\
\text { Accepted: } 19 \text { December } 2017\end{array}$ & \multirow{3}{*}{$\begin{array}{l}\text { The purposes of the study were to evaluate the existing cattle management system, outbreak of } \\
\text { reproductive disorders and farmer's knowledge about cattle rearing. The data were collected from a } \\
\text { sample of } 100 \text { farm household heads selected out of a total of } 1000 \text { farm household heads from Babugonj } \\
\text { upazila through multi-stage random sampling technique interview with a pretested questionnaire during } \\
\text { the period from January to April } 2015 \text {. In this survey, we found that } 65 \% \text { farmers were using semi } \\
\text { intensive housing system of cattle and } 90 \% \text { did not de-worm their cattle regularly. Only } 3 \% \text { farmers } \\
\text { attended a training course related to animal rearing. None of the farmers maintained a register and } \\
\text { calculated the feeding cost per month. About } 97 \% \text { farmers faced the problem of reproductive disorders. } \\
\text { Still } 77 \% \text { farmers wereusing natural insemination for their cow's breeding. A total of } 200 \text { cows' history of } \\
\text { reproductive disorder was collected. The prevalence of anoestrus, repeat breeding, metritis, poor heat } \\
\text { detection, ovarian cyst, uterine prolapse, vaginal prolapse, retained placenta, abortion, still birth, } \\
\text { dystocia, pyometra and laceration of vagina were } 22.0 \%(44), 14.0 \%(28), 9.5 \% \text { (19), } 24.0 \% \text { ( } 48), 1.5 \% \\
\text { (3), } 1.0 \% \text { (2), } 0.5 \% \text { (1), } 9.0 \% 18), 2.0 \%(4), 2.5 \%(5), 3.0 \%(6), 3.0 \%(6) \text { and } 8.0 \% \text { (16), respectively. It } \\
\text { may be concluded that the knowledge of farmer about cattle management is very poor which influenced } \\
\text { the high prevalence of reproductive disorders. The farmers need training on hygienic management and } \\
\text { reproduction of cows. }\end{array}$} \\
\hline $\begin{array}{l}\text { Keywords: } \\
\text { Cows, reproductive disorders, } \\
\text { Management system, Farmers' } \\
\text { nowledge }\end{array}$ & \\
\hline akpau12008@gmail.com) & \\
\hline
\end{tabular}

\section{Introduction}

The cattle population in Bangladesh is rising. Nondescript indigenous zebu cattle are the predominant population with some unplanned crossbreeding at rural areas of Bangladesh. Most of the cattle are reared under subsistence cattle rearing system. Proper management and better reproductive performance are crucial for cattle farming. It is already proved that the yearling calving is the key indicator for profitable farming (Arthur et al., 1996). Therefore it is very crucial to confirm pregnancy within 85 days $(85$ days +270 days pregnancy period $=$ 365 days). Shamsuddin et al. (2001) stated that the lack of clear concept about the timing of insemination in estrus cattle is one of the constraints for profitable farming in aspect of Bangladesh. Arthur et al. (1998) identified sub-fertility as the most important limiting factor in maintaining a good productivity in a dairy farm. Reproductive diseases leading to prolonged intervals between calvings and low conception rate have been reported earlier in Bangladesh (Shamsuddin et al., 1988; Alam and Ghosh, 1994; Shamsuddin et al., 2001). Economy of dairy farming largely depends on pregnancy rate after insemination. The twelve-month calving interval is advantageous for maximal milk yield per cow per year with good economic return (Opsomer et al.,
1996; Paul et al., 2011). It is accepted that bovine genital infections, either specific or non-specific in nature, account for large number of pregnancy failure in cows (Sirohi et al., 1989). Shamsuddin et al. (1988) studied reproductive diseases in large government dairy farm and identified retained placenta, metritis, pyometra, endometritis, cervicitis, persistent corpora lutea, cystic ovaries and nonfunctional ovaries. However, information on the feature of cattle rearing at the southern part of Bangladesh is very negligible. Therefore the aim of this study was to evaluate the existing cattle management system, outbreaks of reproductive disorders and farmer's knowledge about cattle rearing.

\section{Materials and Methods}

\section{Study area}

This study was conducted at Babugonj upazila of Barisal district in Bangladesh. Geographically, Babugonj upazila is located at $22^{\circ} 49^{\prime} 55^{\prime \prime} \mathrm{N} \& 90^{\circ} 19^{\prime} 20^{\prime \prime} \mathrm{E}$ (Fig. 1).

\section{Study period}

The data were collected during the period from January to April, 2015. 


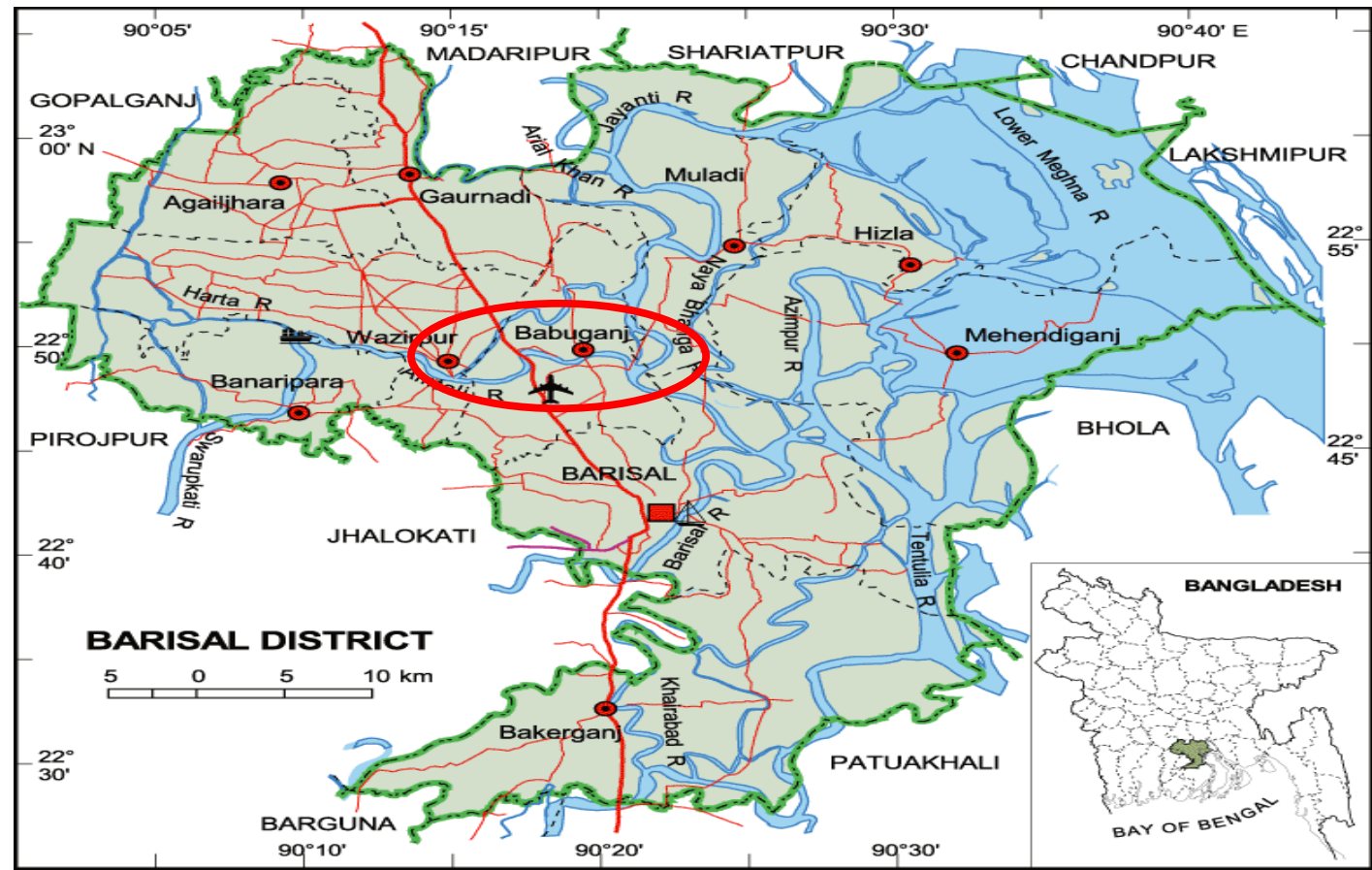

Fig. 1. The map of the study area (Modified from https:// www. google. com. bd/ search? q= barisal district map)

\section{Survey design}

The data were collected from a sample of 100 farm household heads selected out of a total of 1000 farm household heads from Babugonj upazila through multistage random sampling technique. A questionnaire was developed and pretested. The information was collected on housing system, feeding system, milking system, deworming, calf feeding system, colostrums feeding, age of first deworming, congenital abnormality, reproductive disorder, breeding system, disease outbreak and farmers' knowledge and training.

\section{Statistical analysis}

All of the data were organized and coded into the Microsoft ${ }^{\circledR}$ Excel (2010) sheet and the percentages of different parameters were calculated. The significance values of the data were analyzed by Chi-square test using SPSS ${ }^{\circledR}$ software (version 16.0).

\section{Results and Discussion}

\section{Animal management features}

The different cattle management features are presented in Table 1. In this study, we found that $65 \%$ farmers are using semi-intensive housing system. In this case, the cattle are allowed for grazing at the morning and evening for 2-3 hours and kept in cattle shed for the rest of the time. The practice of regular (at every 2-3 months interval) deworming was very low (10\%). About $60 \%$ farmer fed their cattle twice a day. The $100 \%$ farmer could not use any technology for milking their cattle. They were using traditional manual milking system and keptthe calf together with the dam. Most of the farmers did not know the beneficial effect of colostrum feeding as well as the age of first de-worming.
Table 1. Animal management features in the area (household-wise; $\mathbf{n = 1 0 0}$ )

\begin{tabular}{lcc}
\hline \multicolumn{1}{c}{ Factors } & Variables & \% (number) \\
\hline & Intensive & $5(5)^{\mathrm{a}}$ \\
Housing system & Semi-intensive & $65(65)^{\mathrm{b}}$ \\
& Free range & $20(20)^{\mathrm{a}}$ \\
\hline Regular deworming & Others & $10(10)^{\mathrm{a}}$ \\
\hline \multirow{4}{*}{ Feeding times per day } & Yes & $10(10)^{\mathrm{a}}$ \\
& No & $90(9)^{\mathrm{b}}$ \\
\hline Milking system & Once & $15(15)^{\mathrm{a}}$ \\
& Twice & $60(60)^{\mathrm{b}}$ \\
Calf feeding system & Thrice & $20(20)^{\mathrm{a}}$ \\
& More & $5(5)^{\mathrm{a}}$ \\
\hline Colostrum feeding within 6 & Manual & $100(100)^{\mathrm{a}}$ \\
hours after calving & Machine & $0(0)^{\mathrm{b}}$ \\
\hline \multirow{3}{*}{ First deworming of calf } & Together with & $100(100)^{\mathrm{a}}$ \\
& mother & $0(0)^{\mathrm{b}}$ \\
\hline Y, b within a column represent significant differences $(\mathrm{P}<0.05)$.
\end{tabular}

\section{Reproductive features}

The different reproductive parameters are presented in Table 2. About $97 \%$ farmers faced the problem of reproductive disorders. $77 \%$ farmers are using natural insemination for their cow's breeding. The cattle required more than two times service to conceive. The length of post-partum pregnancy period was quite long which more than 100 days was. Most of the farmers $(52 \%)$ reported the cases of calving difficulties. However, about $98 \%$ farmer did not report any congenital defect of the calves. 
Table 2. Reproductive features of cattle in the area (household-wise; $\mathbf{n = 1 0 0 )}$

\begin{tabular}{|c|c|c|}
\hline Factors & Variables & $\%$ (number) \\
\hline Reproductive disorder & $\begin{array}{l}\text { Yes } \\
\text { No }\end{array}$ & $\begin{array}{l}97(97)^{\mathrm{a}} \\
3(3)^{\mathrm{b}}\end{array}$ \\
\hline \multirow{2}{*}{ Breeding system } & $\begin{array}{c}\text { Artificial } \\
\text { insemination }\end{array}$ & $23(23)^{\mathrm{a}}$ \\
\hline & $\begin{array}{c}\text { Natural } \\
\text { insemination }\end{array}$ & $77(77)^{\mathrm{b}}$ \\
\hline \multirow{3}{*}{ Post-partum estrus period } & $\begin{array}{l}\text { Within 30-45 } \\
\text { days }\end{array}$ & $7(7)^{\mathrm{a}}$ \\
\hline & 46-60 days & $11(11)^{\mathrm{a}}$ \\
\hline & $>60$ days & $81(81)^{b}$ \\
\hline \multirow{2}{*}{$\begin{array}{l}\text { Post-partum pregnancy } \\
\text { period }\end{array}$} & 60-80 days & $6(6)^{\mathrm{a}}$ \\
\hline & 80-100 days & $10(10)^{\mathrm{a}}$ \\
\hline \multirow{3}{*}{ Service per conception } & $\frac{>100 \text { days }}{1}$ & $\frac{84(84)^{\mathrm{b}}}{12(12)^{\mathrm{a}}}$ \\
\hline & 2 & $13(13)^{\mathrm{a}}$ \\
\hline & $>2$ & $75(75)^{b}$ \\
\hline \multirow{2}{*}{$\begin{array}{l}\text { Special management of } \\
\text { pregnant cows }\end{array}$} & Yes & $31(31)^{\mathrm{a}}$ \\
\hline & No & $69(69)^{\mathrm{b}}$ \\
\hline \multirow{2}{*}{ Calving disturbances } & Yes & $52(52)$ \\
\hline & No & $48(48)$ \\
\hline \multirow{2}{*}{$\begin{array}{l}\text { Congenital problem of } \\
\text { calf }\end{array}$} & Yes & $2(2)^{\mathrm{a}}$ \\
\hline & No & $98(98)^{b}$ \\
\hline
\end{tabular}

${ }^{\mathrm{a}, \mathrm{b}}$ within a column represent significant differences $(\mathrm{P}<0.05)$.

\section{Reproductive disorders of cattle}

The reproductive disorders are the major causes of reproductive infertility in cows that affect the total annual calf crop, resulting in great economic loss in Bangladesh. In this study, a total of 200 cow's history with reproductive disorder was collected, which included anoestrus $22.0 \%$ (44), repeat breeder $14.0 \%$ (28), metritis9.5\% (19), poor heat detection $24.0 \%$ (48), ovarian cyst $1.5 \%$ (3), uterine prolapsed $1.0 \%$ (2), vaginal prolapsed $0.5 \%$ (1), retain placenta $9.0 \%$ (18), abortion $2.0 \%$ (4), still birth $2.5 \%$ (5), dystocia $3.0 \%$ (6), pyometra $3.0 \%$ (6) and laceration of vagina $8.0 \%$ (16)(Figure 2). Our findings are similar to that of Maruf et al. (2014) who got the highest proportion of cows that suffered from anoestrus (22.2\%) and the lowest proportion of cows that had laceration of vagina $(0.7 \%)$. The retained placenta $(19.8 \%)$, repeat breeding $(16.2 \%)$, metritis $(19.1 \%)$, poor heat detection (6.8\%) were diagnosed as major reproductive problems at the milk pocket areas of Bangladesh. The prevalence of anoestrus was $5.1 \%$, which was lower than that $(26.5 \%)$ observed by Bitew and Prasad (2010) in South West Ethiopia. The prevalence of reproductive disorders in our findings was comparatively lower than that of the study of Mekonnin et al. (2015) who recorded the prevalence rates of reproductive problems asanestrus (37.8\%), repeatbreeding (21.0\%), dystocia (11.6\%), retained fetal membranes $(11.5 \%)$, endometritis $(6.6 \%)$, abortion $(6.4 \%)$, prolapsed uterus/vagina (2.9\%), stillbirth $(2.0 \%)$ and freemartin $(0.2 \%)$. The higher prevalence of anoestrous may be attributed to variations predisposing factors such as nutritional status, manage mental conditions, hormonal imbalance and reproductive tract infections, for instances. The number of anoestus cattle in the studied population was high which might be due to poor nutrition, as farmers served house hold wastage, straw and some grass only as the diet.

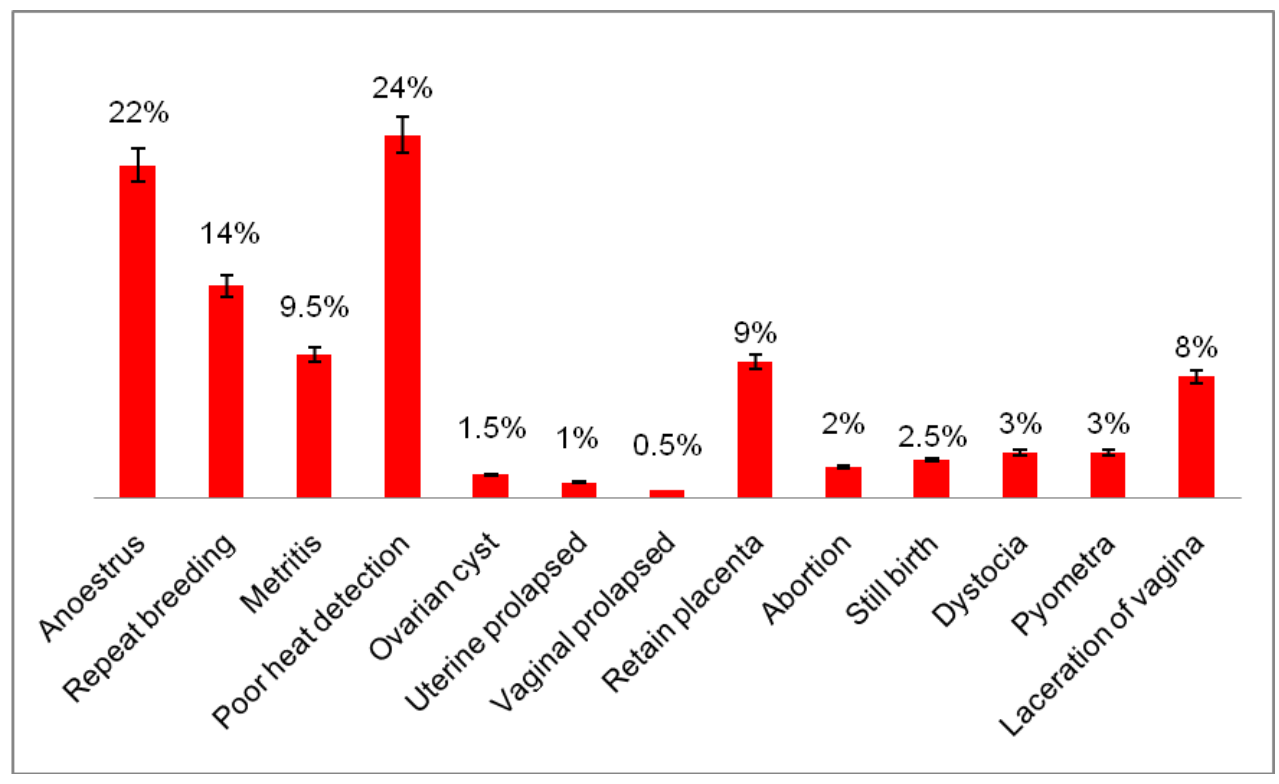

Fig. 2. Reproductive disorders in cows $(n=200)$ 
Farmer's knowledge for animal management

In this study, we also asked the farmers $(n=100)$ about their knowledge of animal rearing. We found that only $3 \%$ farmers attended training course related to animal rearing (Table 3). None maintained a register or calculated the feeding cost per month. As they served house hold waste to their animals, so they did not calculate the cost of feeding. However, only $2 \%$ farmer calculated the overall profit cost.

Table 3. Farmer's knowledge analysis

\begin{tabular}{lcc}
\hline Indicators & Variables & $\boldsymbol{\%}(\mathbf{n})$ \\
\hline \multirow{2}{*}{ Attend training course } & Yes & $3(3)^{\mathrm{a}}$ \\
& No & $97(97)^{\mathrm{b}}$ \\
\hline \multirow{2}{*}{ Record keeping system } & Yes & $0(0)^{\mathrm{a}}$ \\
& No & $100(100)^{\mathrm{b}}$ \\
\hline Knowledge about feeding cost & Yes & $0(0)^{\mathrm{a}}$ \\
analysis per month & No & $100(100)^{\mathrm{b}}$ \\
\hline Idea about medicinal cost per & Yes & $6(6)^{\mathrm{a}}$ \\
month & No & $94(94)^{\mathrm{b}}$ \\
\hline \multirow{2}{*}{ Calculation of overall profit } & Yes & $2(2)^{\mathrm{a}}$ \\
& No & $98(98)^{\mathrm{b}}$ \\
\hline Knowledge about cleaning of & Yes & $13(13)^{\mathrm{a}}$ \\
cattle shed & No & $87(87)^{\mathrm{b}}$ \\
\hline $\mathrm{a}, \mathrm{b}$ within a column represent significant differences $(\mathrm{P}<0.05)$
\end{tabular}

\section{Conclusion}

It may be concluded that the knowledge of farmers about cattle rearing is very poor. The reproductive capability of cows is also poor and the prevalence of reproductive disorders is high in the study area due to the poor knowledge of farmers. Therefore it is suggested that the farmers need training and continuous veterinary services for successful dairying in Bangladesh.

\section{Acknowledgment}

The authors express their cordial gratefulness to the Research and Training Center (RTC) of Patuakhali Science and Technology University, Patuakhali,
Bangladesh for the financial support and providing scope for this research.

\section{References}

Alam, M.G.S. and Ghosh, A. 1994. Reproductive performance in cows: it's relationship to parity and season. Bangladesh Vet. J., 22: 51-61.

Arthur, G.H., Noakes, D.E. and Pearson, H. 1996. Veterinary Reproduction and Obstetrics. Theriogenology $6^{\text {th }}$ ed. Baillier Tindall UK, pp. 83-85.

Arthur, G.H., Noakes, D.E., Pearson, H. and Parkinson, T.J. 1998. Veterinary reproduction and obstetrics. $7^{\text {th }}$ ed. W. B. Saunders Company Limited London Philadelphla Toronto Sydney Tokyo. pp. 345-388.

Bitew, M.and Prasad, S. 2010. Study on Major Reproductive Health Problems in Indigenous and Cross Breed Cows in and Around Bedelle, South West Ethiopia. J. Ani. Vet. Advan. 10: 723-727.

Maruf, A.A., Paul, A.K., Bonaparte, N., Bhuyian, M.H. and Shamsuddin, M. 2014. Reproductive Disorders that Limits the Reproductive Performances in Dairy Cows of Bangladesh. J. Embryo Trans. 29(2): 189-194.

Mekonnin, A.B., Harlow, C.R., Gidey, G., Tadesse, D., Desta, G., Gugssa, T., Riley, S.C. 2015. Assessment of Reproductive Performance and Problems in Crossbred (Holstein Friesian $\mathrm{X}$ Zebu) Dairy Cattle in and Around Mekelle, Tigray, Ethiopia. Ani.Vet. Sci. 3 (3): 94-101.

Opsomer, G., Mijtem, P., Coryn, M. and Kruif, A.D. 1996. Postpartum anestrus in dairy cows, a review. Veterinary Quarterly. 18 (2): 68-75.

Paul, A.K., Alam, M.G.S. and Shamsuddin, M. 2011. Factors that limit first service pregnancy rate in cows at char management of Bangladesh. Livestock Res. Rural Devel. 23(3): Article\#57

Shamsuddin, M., Alam, M.G.S. and Ahmed, J.U.1988. Reproductive Disorder of cross breed cows. Bangladesh Vet. J. 22(24):21-28.

Shamsuddin, M., Bhattacharjee, J., Goodger, W.J., Momont, H., Frank, G., Talukder, A.K., Akteruzzaman, M. 2001. Communitybased productivity veterinary service for smallholder dairy farmers in Bangladesh. In: Suntainable improvement of animal production and health, Food and Agriculture Organization of the United Nations. Rome: pp. 247-253.

Sirohi, N.S., Monga, D.P. and Knar, S.K. 1989. Microbiological studies on some reproductive disorders of cattle. Indian J. Ani. Sci. 59 (5): 537-541. 